\title{
DRYING TECHNIQUES OF SOME SELECTED ORNAMENTAL FLOWERS-A REVIEWS
}

\author{
Prexa Rathod ${ }^{1}$ \\ Department of Botany, Bioinformatics and Climate Change Impacts Management, University School \\ of Sciences, Gujrat University, Navrangpura, Ahmedabad-9
}

\author{
Milan Vala ${ }^{2}$ \\ Department of Botany, Bioinformatics and Climate Change Impacts Management, University School \\ of Sciences, Gujrat University, Navrangpura, Ahmedabad-9
}

\section{Bharat Maitreya ${ }^{3}$}

Department of Botany, Bioinformatics and Climate Change Impacts Management, University School of Sciences, Gujrat University, Navrangpura, Ahmedabad-9

Article DOI: https://doi.org/10.36713/epra6775

DOI No: 10.36713/epra6775

\begin{abstract}
Drying of flowers is the method of maintenance of flowers or removing water and moisture. Dehydration is most important for getting dry flowers. There are Many different types of methods use for removing moisture contain from flowers are air drying, embedded (sand, borax, silica gel, and other materials) press drying, freeze drying, microwave oven drying, hot air oven drying, Glycerin drying, freeze drying. Chrysanthemum is one of the most widely cultivated garden flowers and ranks popularity. The Chrysanthemum flower has fully double flowers with flat petals and the central disc is generally absent. Many of the commonly grown marigolds are cultivars of African and French marigolds. Flower petals of African marigold are the best source of carotene for coloring foodstuffs. From the dried flowers varied manufacture are made and use like petal embedded handmade paper, press dried flower products, candle making, pot pourri, floral jewelry etc. This dried plants and flowers materials also used in industry. For chrysanthemum embedded drying is the best in which flower shape, size, structure, colour are maintained and for marigold microwave and air drying techniques are best in size, colour, shape, colour are maintained.

KEYWORDS: Drying Techniques, Chrysanthemum, marigold, embedded, microwave
\end{abstract}




\section{SJIF Impact Factor 2021: 8.013| ISI I.F.Value:1.241| Journal DOI: 10.36713/epra2016 ISSN: 2455-7838(Online) EPRA International Journal of Research and Development (IJRD)

\section{INTRODUCTION}

A. Drying of flowers is the method of maintenance of flowers or removing water and moisture. Dehydration is the most important for getting dry flowers. There are many different types of methods use for removing moisture contain from flowers are air drying, oven drying, embedded drying (sand, borax, silica gel and other materials) microwave oven drying, freeze drying, press drying.

B. Drying methods

1) Air drying. This one of the simplest and cheap method of drying techinques.it is conceive as the oldest and uncomplicated method for drying flowers. The simple and easiest and most effective way to dry. Flowers are tied in twine, ribbon and hang them warm air in the dark room this process take 1-2 week for complete dry and its depends upon atmospheric humidity, temperature, moisture, shape of flowers and air velocity. (Datta, S.K.,2015).

2) Sun drying: Sun drying is requiring a good deal of care in this method the plant equipment is embedded in the sand for drying. This medium is filed in container and reveal regular to the sun for expeditious dehydration. India is followed this method for drying many flowers. In the sand the flowers are embedded in flipped from and put in the sun light for drying for day or two (Murugan. A et al.,2007)

3) Press drying. Press drying is one of the most common and simple method for drying flowers. This method is still considered to be the most simplified or familiar method for preserving flowers and foliage. In this flowers shape cannot be maintained. Buy original colour is retained. For drying it take up to 3-4 weeks because it depends on the moisture content of tissues in flowers. (Datta S.K et al., 2015)

4) Hot air drying. for expeditious dry in convention chamber, it has fan inside. For quick dehydration. In this method temperature should maintain between $30^{\circ}$ to $35^{\circ} \mathrm{C}$. hot air drying method take few hours to few days for completely to dry flowers. This method is advantage as atmosphere does not have any role for dehydration. This process is quick and the quality of the product is very good. (Raval et al.,2020)

5) microwave drying: this method takes only a 510 minutes in microwave. Flowers embedded in sand. After this process flowers are taken out from microwave and put in room temperature for some time because flower materials completely dried. The embedded flower materials were dehydrated in microwave oven. Microwave oven dried flowers looks fresher and more attractive and colorful than that obtained by different methods. (P. Radha rani et al.,2015)

6) embedded drying. embedding is the one of the most vital processes for removing moisture contain in this method. Retention flowers petals and color is good. Silica gel, borax, corn Meal, sand disused for at the base of flower either before or after drying. In this method use containers like desk, trays, earthen pots etc. container size depends upon the size of flowers to be embedded. In this method moisture content in the flower is perfectly absorbed by around material. Sand or silica gel is poured without are hurring, carefully and gently so that flowers filled up $2.5 \mathrm{~cm}$ from bottom. Silica gel is the perfect desiccant. Drying process is complete when flowers are crumble and dry to touch, but not brittle. For removing water contain from flowers, silica gel (60-20 mesh) is the perfect absorptive. (Jain. R et al.,2016)

\section{SELECTED FLOWERS}

\section{A. Marigold}

Marigold (Tagets eracta L.), belongs to the family asteraceae. Marigold commercially cultivated in many countries for ornamental, medicinally and industrial's uses. African marigold is one the vital for business flower crops. Marigold native is central and south America, especially Mexico. Marigold is Cleary organizing in two groups., African marigold and French marigold (Tagets Patula L) In Karnataka, Andhra Pradesh and Maharashtra have big areas under contract cultivation of marigold. Most of quintessence units are located in Kerala and Andhra Pradesh. The African marigold (Tagets eracta) have big, reduplicate, yellow to orange flowers from mid-summer to frost. Flower probability measure up to $12.7 \mathrm{cmc}$ across. Marigold maximum high varies from 24.5 to $90 \mathrm{cms}$. African marigold are super bedding plants. African marigold is also adverted to as American marigolds (Manik $\mathrm{h}$ et al.,2015), (Misra et al.,2016) Duration of flowering the genetic control of the nature and changes in their rate suitable to environmental wager it could be the possible case of review venation. (Panwar et 
al., 2013) reported that in African marigold common high grade for duration of flowering.

\section{B. Chrysanthemum}

Chrysanthemum is belonging to the asteraceae family. Chrysanthemum is one of the nearly all over widely cultivated garden flowers and line in likely next to the rose is approval. Chrysanthemum can be arranged in classes inside many groups due to shape, size and colour of the flowers. The primary groups are under:

a) Incurved: The ray flowers turn upwards and inwards at the middle of the blossom to from a globe-shaped.

b) Incurving. Ray inflect loosely and asymmetrical and do not from a ball as upon.

c) Reflexed: The flowers are plunging in one or not another that five rows with a primary central disc.

d)Pompon: flowers are very tiny sized disc is absent or covert.

e) Rayonnaetes: the petals are quilled. (Misra et al.,2016)

Research in dry flowers in India is limited and published information on dry flowers techniques is approximately nominal. According to Bull et al., 1999 chrysanthemum, marigold, roses are the best suited to hot air drying and microwave drying. Silica gel is ideal drying agent Prasad et al.,1997. Singh and Dhaduk, 2005 observed that drying process at high temperature, oven showed fast result better than river sand and borax. Arvinda and Jayanthi., 2004 Standardized the drying technique methods like oven drying, sun drying, microwave drying for chrysanthemum (button local type) flowers and constitute that microwave drying with silica gel gave the perfect result for retaining colour, petals or shape of flowers. While in oven drying techniques white sand was found the perfect overall acceptability. Bhalla et al., 2006 studied that most carotene and most least size reduction obtained when flowers were embedded in silica gel and dry on $3^{\circ} \mathrm{C}$ for $24 \mathrm{~h}$ in hot air oven and microwave oven for 35 seconds for drying. According to Champoux et al.,1999 flower hung in dark room that took maximum 8 to 9 days for drying. According to Paul and shyalla 2002. the platform harvesting for other flower varies according the species and flower desired. According to Bhutani 1990 if sheets are kept in oven at an appropriate temperature that drying time can be less. Smith et al., 1993 reported that flowers like globe amaranth, chrysanthemum, and many different type of flowers unbroken and long lasting can be picked up for air drying techniques partially opened; as they flower proceed to open duration drying and some different are picked when they are perfectly mature. (P Radha rani et al., 2015) studied that the numeral of time taken to drying the flower is more in river sand drying method i.e. 2 weeks, whereas chrysanthemum, daisy and gladioli has taken minimum amount of time approximately 8 days. Chrysanthemum, carnation etc. suitable for sun drying methods.

According to Datta et al.,1997, The drying method can be quacked by placing the herbarium press under a hot air oven at $45-50^{\circ} \mathrm{C}$ for 24 hours. Embedded drying is admitting to undo petals becoming smaller in size and preserving the good flowers petals, shape, and colour condition. Datta 1997 reported that the Blotting papers, as well flowers are required to turn on as an alternative dry as storage of water contain and cellulose leads to microbial attack. For the most part, this method took 1-3 week but, time can be reducing by keeping on the oven at the proper temperature. Jain et al, 2016 reported that the high temperature may exact the process but damages the flower pigments. It is too reported that the condition of flowers uncovers under $45^{\circ} \mathrm{C}$ temperature then flowers like chrysanthemum, gerbera, helipterum is dried within 48 hours where French marigold and African marigold are taken 72 hours and 96 hours respectively for perfect flower drying. According to Rengasamdy et al.,1999 observed that the sun drying is rapid process of dehydration and it is handy and depended on atmosphere. Sujata et al., 2002 noted that flowers like chrysanthemum and zinnia dried good with minimum shrinkage when dried under sun. Bhutani et al., 1990 recommended during study embedding method including with oven drying at $45^{\circ} \mathrm{C}$ to $50^{\circ} \mathrm{C}$ degree about 45 hours for drying of heliichrsum, chrysanthemum, acroclinum. According to Joykumar et al., 1997 that the hot air oven drying techniques at $50^{\circ} \mathrm{C}$ cook beady time for drying aster (36 hours) and chrysanthemum (22 hours) flowers. Rengasamy et al.,1999 reported that Tagets patula took 72 hours in oven at $40-44^{\circ} \mathrm{C}$ for drying. Kumar and parmar suggested that the flowers were dried at $45-49^{\circ} \mathrm{C}$ for $24-28$ hours in oven drying and 
then accord to quieten in open for a few hours and then taken out and used. According to Dahiya et al.,2003 get the best quality dried flowers having lowest water contain weight and high visual score at $50^{\circ} \mathrm{C}$ for 48 hours in the oven drying in chrysanthemum. Gouin et al.,1993 listed that some flowers like chrysanthemum, gladiolus and plasy are good for embedding in sand drying method. Bhalla et al.,2002 said that silica gel gave best result while river sand was not given result of overall admissibility of flowers. Moona et al., 2004 found that minimum size change and maximum carotenoid content was received when flowers were embedded in silica gel. Arvinda and Jayanthi et al.,2004 studied that meanwhile different media silica gel as a medium noted maximum score of texture and shape in chrysanthemum. Datta et al.,1999 embedded flower with silica gel is suitable and put in room temperature for perfectly drying.

According to Sansakri. A and Anand. M et al.,2014 microwave oven drying technique process is done instead of entering in liquid state. As a result, products get from this process are retain their original size, shape and colour. In embedded method 40 to $45^{\circ} \mathrm{C}$ degree temperature electrically operated hot air oven controlled it used for drying flowers. Jain and Singh et al.,2016 noted that the India is exports $70 \%$ of the total share of floriculture products. Dried flowers and plant materials is important. According to Bhutani et al.,1990, Bhalla and Sharma, decorative floral craft item for drying techniques like oven drying, sun drying, microwave drying, freeze drying, embedded drying, air drying it can be used.i.e. cards, wall hanging, floral design, calendars etc. According to Baskaran et al.,2009 studied on condition that store in dry from remain dried beautiful for longlasting periods. Dried chrysanthemum flowers are remarkable requirement in the global trade. For that reason, remain in this view the formidable capacity of dried chrysanthemum flower the relevant studies were made to systematize the dehydration technology for chrysanthemum flowers (Dandranthema grandiflorum Tzvelev) A real contents of published works included research and reviews are attainable in embedding drying method and dehydration of perlite, powdery particles, borax, silica gel river sand and their compounds. Types of a size. The main parts of dehydration plant ornamental and flowers leaves through embedding drying techniques Orduno and Baltazaret et al.,1995, Bhalla et al., 2006, Bhattacharjee and De et al., 2003. According to Gouin et al.,1994 reported that listed some flowers and leaves like chrysanthemum, gladiolus, butterfly weed, black Eye-Susan, anemone and pansy is good for shade drying. According to Joykumar 1997 shade drying needed longer time for drying, 66 to 90 hours reputedly in flowers like chrysanthemum and aster. Bhutani et al., 1990 asserted that flowers and leaves could be embedded in white silver sand in plastic, earthen container or metallic gave a good result. Smith et al.,1993 suggested storage of dried flowers with river sand in a strong carton to save the flower petals from breaking petals. Datta et al., 2001 reported that material which used for flowers and foliage and embedding drying should be good. It should not chemically act with flower parts. Fine sand has been found to be the good material for embedding because it is simply to handle, heavy and doesn't act with water vapor. Lourdusamy et al.,2001 reported that floral like small size marigold, chrysanthemum, pansies embedded in sand in an upside down fashion was dry in days. According to sujatha et al.,2001 flowers like zinnia and chrysanthemum dried good with minimum shrinkage after placing them in a box containing stand and it takes few days for perfect drying. Pertuit et al., 2002 suggested that burying the flowers in a mixture of sand and borax $(2: 1)$ result in floral that are little bit stiff than those preserved with "hang and dry" method, but the partials tend to cling to some flowers. Sand have rough border may produce little holes in the flower petals. Similarly, sing and Dhaduk et al., 2004 found that borax reason dim of colour and rough texture of petals. According to Datta et al.,1999 embedded flowers and foliage with silica gel in a right holder and kept in room temperature for perfect drying. Orduno and Baltazar et al.,1995 noted that river sand or sea sand in attachment of borax for drying gerbera and rose they have reported that the rose dry good in river sand which include high ratio of borax within 15-20 days' period, when sea sand and river sand with low ratio of borax for 10-15 day best for gerbera. According to Joyce et al.,1998 Glycerinisation is comparatively cheap 


\section{SJIF Impact Factor 2021: 8.013| ISI I.F.Value:1.241| Journal DOI: 10.36713/epra2016 ISSN: 2455-7838(Online) EPRA International Journal of Research and Development (IJRD) \\ Volume: 6 | Issue: 4 | April 2021 \\ - Peer Reviewed Journal}

and less expensive, glycerin has a high water attracting capacity. Westland et al.,1995 reported that preserving leaves and berries in glycerin and hot water solution brought leaves and berries put into almost long lasting category. Paul and shyalla et al.,2002 studied that the in glycerin drying, feature of the product was best as moisture in flower was diverted by a mixture and glycerin. The use of glycerin in drying method is reported to be successful with almost all foliage. Semant et al.,1993 observed that one stage of glycerin mixed with 2 parts of hot water was typical mixture for twigs of 26 plant species to comprise at room temperature. The equipment should in solution as late as full absorption has taken place. According to Prasad et al.,1997 reported that the Glycerin serves as a best source for microorganisms, so a pinch of antibiotic is important to detain microbial growth in the dried specimens. Bhattacharjee and De et al.,2003 reported that many cultivars of carnation florals were cryodried and resided naturalistic in looks after being placed in freeze dried $\left(-20^{\circ} \mathrm{C}\right)$ for 7 days. White et al., 2002 has noted that microwave oven drying floral were looked more colorful and fresh than obtained by other techniques. Chen et al., 2000 had appraise the effect of different freezing time (2 -4 hours), vacuum drying temperature $\left(27^{\circ} \mathrm{C}, 37^{\circ} \mathrm{C}, 47^{\circ} \mathrm{C}\right)$ and freezing temperature $\left(-35^{\circ} \mathrm{C}\right)$ on water content, petals, stems and colour of roses. Sohn et al., 2003 studied that the impact of freeze drying for 15 days on the texture and colour of roses hybrid (CVS Tineke, Saphir, Roulette, Golden Gate, Rote Rose). According to Datta et al.,1999 had given the drying time for different flowers in hot air oven at temperature of $45^{\circ}-50^{\circ}$ C. he had also noted the name of flowers right for oven drying method.

\section{CONCLUSION}

Based on literature survey, here we have concluded that for chrysanthemum flower, microwave drying techniques are the best in which shape, size, colour are maintained compared to other and for marigold flowers wave and air drying, microwave and hot air drying is best in colour, size, shape, texture, maintain. So we can dry flowers by using this types techniques and make so many products like dry flowers jewelry, pot, pourri, candle making, photo frames, pressed dried products, handmade paper. The dehydration technology, standardizes by CSIR-NBRI, will help to industry for dry flowers in agrestic areas.

\section{REFERENCES}

1. Akshaya, H. R. (2015). Standardization of dehydration and storage techniques for higher retention of a techniques for chrysanthemum (Dendranthema grandiflora Tzvelev cv. Button type Local) flowers. Journal of Ornamental Horticulture, 7(3and4), 370-375.

2. Bryan, L. (2000). Drying Flowers and Herbs. Northwestern University Press. Bhutani, J. C. (1993). Economic potential of dried flowers. Agricultural Marketing, 36(1), 43-46.

3. Bhutani, J. C. (1990). Capturing nature, a way with flower "Everlastings". Indian Horticulture, 34(4), 15-19.

4. Bhattacharjee, S. K., \& De, L. C. (2003). Dried flowers and plant parts. Advanced commercial floriculture, 162, 173.

5. Bhalla, R., \& Sharma, B. (2002). Dry flowers status, scope and potential. Production and management of flower crops. Division of Floriculture and Landscaping, IARI, New Delhi, 162-171.

6. Bhutani, J. C. (1995). Drying of flowers and floral craft. Advances in Horticulture Ornamental Plants, 12, 1053-1058.

7. Brown, S. P., White, P., Tija, B., \& Sheehan, M. R. (2013). Drying and preserving plant materials for decorative uses. EDIS, 2013(11).

8. Baskaran, V., Jayanthi, R., Janakiram, T., \& Abirami, K. (2010). Evaluation of post-harvest quality of some cultivars of chrysanthemum. Journal of Horticultural Sciences, 5(1), 81-83.

9. Chen, W., Gast, K. L., \& Smithey, S. (2000). The effects of different freeze-drying processes on the moisture content, color, and physical strength of roses and carnations. Scientia horticulturae, 84(34), 321-332.

10. Datta, S. K. (2016). Dehydration of flowers and foliage and floral craft. EVERYMAN'S SCIENCE, 224.

11. Datta, S. K. (1999). Dehydrated flowers and foliage and floral craft. Floriculture and Landscaping. Naya Prakash, Kolkata.

12. Datta, S. K. (2004). Dehydration of flowers: A new diversified product for floriculture industry emerging trends in Ornamental Horticulture. Ind. Soc. Orn. Hort, 157-161.s

13. Dahiya, D. S., Unnikrishnan, D., Gupta, A. K., Sehrawat, S. K., \& Siddiqui, S. (2002, August). Dehydration of annual chrysanthemum (C. coronarium). In XXVI International Horticultural Congress: Asian Plants with Unique Horticultural 


\section{SJIF Impact Factor 2021: 8.013| ISI I.F.Value:1.241| Journal DOI: 10.36713/epra2016 ISSN: 2455-7838(Online) EPRA International Journal of Research and Development (IJRD) \\ Volume: 6 | Issue: 4 | April 2021 \\ - Peer Reviewed Journal}

Potential: Genetic Resources, Cultural 620 (pp. 359-362).

14. Dhatt, K. K., Singh, K., \& Kumar, R. (2007). Studies on methods of dehydration of rose buds. Journal of Ornamental Horticulture, 10(4), 264-267.

15. Dilta, B. S., Sharma, B. P., Baweja, H. S., \& Kashyap, B. (2011). Flower drying techniques-A review. International Journal of Farm Sciences, 1(2), 1-16.

16. Geetha, C. K., Shalini, M., Rajeevan, P. K., \& Valsalakumari, P. K. (2002). Effects of desiccants on drying of Indian blue water lily. Nymphaea stellata, 25-27.

17. Jain, R., Janakiram, T., \& Kumawat, G. L. (2016). Drying Techniques in Ornamental Plants. Commercial Horticulture, 501-12.

18. Joykumar, N. (1997). Studies on the drying characteristics of some important flowers. Unpublished M. Sc. Thesis, University of Agricultural Sciences, Bangalore, India.

19. Joyce, D. C. (1996, October). Dried and preserved ornamental plant material: Not new, but often overlooked and underrated. In III International Symposium on New Floricultural Crops 454 (pp. 133-146).

20. Lourdusamy, D. K., Vadivel, E., \& Azhakiamanavalan, R. S. (2001). Research and development in dry flower technology. Floriculture Today, 5, 8-13.

21. Malcolm, H. (1994). Guide to arranging dried flowers. Step by step handbook of growing, drying and displaying, Dorling Kindersley Ltd, London, 120.

22. Mishra, S., Dwivedi, A. K., \& Kulshreshtha, K. (2014). To study the effect of texture of flower petal and moisture content during floral dehydration. International Journal of Latest Research in Science and Technology. [Internet], 144-146.

23. Moona, L. (2004). Standardization of drying techniques of chrysanthemum (Dendranthema grandiflorum Tzevlev.) (Doctoral dissertation, $M$. Sc. thesis).

24. Orduno, C. A., \& Baltazar, B. (1995). Effect of different mixtures of sand and borax on the drying of three flower species. Revista Chapingo Serie Horticulturae, 1(3), 93-97.

25. Paul, D., \& Shylla, B. (2002). The art of flower drying. Floriculture Research Trends in India, 4146.

26. Panwar, S., Singh, K.s P., \& Janakiram, T. (2013). Genetic variability, heritability and genetic advance in African marigold (Tagetes erecta L.) genotypes. Progressive Horticulture, 45(1), 135 140.
27. Prasad, J. J. K., Pal, P. K., \& Voleti, S. R. (1997). Drying of flowers: an upcoming industry. Floriculture Today, 2, 20-23.

28. Ranjan, J. K., \& Misra, S. (2002). Dried flowers: a way to enjoy their beauty for a long period. Indian Horticulture (India).

29. Raval, R., Jayswal, S., \& Maitrey, B. Drying Techniques of Selected Flowers-A Review.

30. Raj, D. (2006). Drying of attractive plant parts and flowers. Advances in ornamental horticulture, 5, 189-198. Raghava, S. P. S. (1998). Pusa Narangi Gainda and Pusa Basanti Gainda: New Marigolds. Indian Horticulture, 43, 31.

31. Rengasamy, P., Arumugam, T., Jawaharlal, M., Ashok, A. D., \& Vijayakumar, M. (1999). Dry flowers. A profitable floriculture industry. Kisan World, 26, 61-62.

32. Singh, A., Dhaduk, B. K., \& Shah, R. R. (2003). Effect of dehydration on post harvest life and quality of zinnia flowers. Journal of Ornamental Horticulture, 6(2), 141-142.

33. Sankari, A., \& Anand, M. (2014). Process of making-waste into wealth-dry flower technology. Asian Journal of Horticulture, 9(2), 466-483.

34. Semant, P. K. S., Dash, D. K., Barik, L. R., \& Dhar, A. N. (1993). Effect of glycerine on preservation of foliage of some ornamental plants. Orissa Journal of Horticulture, 21, 73-75.

35. Singh, A., \& Dhaduk, B. K. (2005). Effect of dehydration techniques in some selected flowers. Journal of Ornamental Horticulture, 8(2), 155-156.

36. Singh, A., Dhaduk, B. K., \& Shah, R. R. (2003). Effect of dehydration on post harvest life and quality of zinnia flowers. Journal of Ornamental Horticulture, 6(2), 141-142.

37. Singh, H. P. (2005). Current status of floriculture in India. Flor. Today, 5(6).

38. Sell, R., \& Aakre, D. G. (1993). Dried and FreshCut Flowers.

39. Singh, A., Dhaduk, B. K., \& Shah, R. R. (2004). Effect of different temperatures and embedding media on flower dehydration of Zinnia (Zinnia linearis Benth.). Indian Journal of Horticulture, 61(3), 249-252.

40. Smith, R. C., \& Laschkewitsch, B. (1992). Methods of preserving flowers.

41. Sujatha, A. N., Damodaran, T., \& Shiva, K. N. (2001). Dry flower industry in Andamans. Kisan World, 28, 28.

42. Sindhuja, S., Padmalatha, T., Padmavathamma, A. S., \& Prasad, A. L. N. (2016). Studies on Different Methods of Drying in Carnation. Indian Horticulture Journal, 6(1), 122-127. 
SJIF Impact Factor 2021: 8.013| ISI I.F.Value:1.241| Journal DOI: 10.36713/epra2016 ISSN: 2455-7838(Online) EPRA International Journal of Research and Development (IJRD)

43. Sharavani, C. S. R., \& Sree, G. D. (2018). Dry Flowers-A Boon to Floriculture Industry. Journal of Postharvest Technology, 6(3), 97-108.

44. Son, K. H., Kwon, H. J., \& Kim, E. Y. (2003). Effects of drying methods on shape and color of Rosa hybrida. Horticultural Science \& Technology, 21(2), 136-140.

45. Unnikrishnan, D., Gupta, A. K., Sehrawat, S. K., Siddiqui, S., \& Dahiya, D. S. (2002, August). Dehydration of Annual Chrysanthemum (C. coronarium). In XXVI International Horticultural Congress: Elegant Science in Floriculture 624 (pp. 385-388).

46. Westland, P. (1995). Step by Step: Dried Flowers. Smithmark Pub.

47. Wilson, D. E. E. N. A., Attri, B. L., \& Sharma, S. K. (2013). Evaluation of different methods for drying of chrysanthemum flowers. Asian Journal of Horticulture, 8(2), 743-745.

48. White, P., Tjia, B., \& Sheehan, M. R. (1982). Drying and preserving plant materials. CircularFlorida Cooperative Extension Service (USA).

\section{WEB LINKS}

1. http://www. kaepsmlin. com/tips. html.

2. http://www. kaepsmlin. com/tips. html.

3. http://www. techno-preneur. net/informationdesk/sciencetech-magazine/2007/Dec07/Dry-flower.

4. http://hgic. clemson. edu/factsheets/hgic, 1151.

5. https://www.researchgate.net/publication/32539805 6.

\section{BOOKS}

1. Commercial flower cultivation by Dr. Kaushal kumar Misra and Dr. Satish Chand,2016.

2. Dry flowers technology dehydration of flowers, foliage and floral craft by Dr. Subodh Kumar Datta,2015. 